\title{
Law and Economic Growth in China: A Case-Study of the Stock Market
}

\author{
Zhong ZHANG* \\ School of East Asian Studies, University of Sheffield, Sheffield
}

\begin{abstract}
It is widely accepted that law is essential for economic growth. Prominent economists in China have repeatedly called for strengthening the legal system so that the economy can continue to grow. Nevertheless, the fact that China has been able to achieve rapid economic growth while the law is weak seems to cast doubt on the significance of law. It is even suggested that China is a counter-example to the importance of law and, more provocatively, it is argued that China's economy grew rapidly not "in spite of," but "because of," weak law. To gain a richer and deeper understanding of law in China's economic growth, this paper conducts a case-study of China's stock market by examining its growth history and legal development. It is found that China has built from scratch a complex legal and regulatory system governing the stock market, which actually played a critical role in supporting the growth of the market. However, the trajectory of development was law following market growth, which was in turn caused by ideological and political liberalization. On the other hand, the market did not grow to its full potential and currently it faces serious challenges to fulfil the task of supporting the development of the economy, and the fundamental reason is political and ideological restrictions; likewise, the improvement of law for investor protection has not been sustained, for which similarly politics and ideologies offer an explanation. The experience of the stock market suggests that, while law is indispensable for sustaining China's economic growth, political and ideological liberalization is fundamental in that it is not only necessary to free up the economy so that it can continue to grow in the first place, but also crucial to further strengthening the whole legal system.
\end{abstract}

Keywords: law, economic growth, stock market, China, case-study

\section{INTRODUCTION}

China's economy has slowed down considerably since the global financial crisis and the gross domestic product (GDP) growth rate dropped from $14.2 \%$ in 2007 to $6.7 \%$ in $2016{ }^{1}$ As the economy decelerates, the debate about the sustainability of China's economic growth intensifies. Most of the debate centres on macroeconomics as well as China's demographic,

* Lecturer in Chinese Studies in the School of East Asian Studies, University of Sheffield. The author thanks participants at the Plenary session 2 of the 2017 ECLS Annual Conference in Leiden for their comments. Correspondence to Dr Zhong Zhang, 6/8 Shearwood Road, Sheffield, S10 2TD, UK. E-mail address: zhong.zhang@ @heffield.ac.uk.

1. World Bank (2017). 
environmental, and natural-resource capacity. ${ }^{2}$ Alternatively, some prominent economists and legal scholars call for strengthening the legal system, arguing that it indispensable for sustaining China's economic growth. ${ }^{3}$ The Communist Party of China (CPC) itself has decided to "comprehensively advance governing the country according to law" and one important consideration is "to complete the building of a moderately prosperous society in all respects." 4

The classic view on law and economic development is that law is essential for economic growth. ${ }^{5}$ In particular, property right and contract law are key, because they provide a critical incentive for wealth creation and enhance certainty and predictability that are necessary for commercial transactions. ${ }^{6}$ However, the common perception about China's experience is that China has been able to maintain a high growth rate despite the law being weak. It is said that law provides little explanatory power for China's economic growth. ${ }^{7}$ It is even suggested that China is a counter-example to the significance of law ${ }^{8}$ and, more provocatively, it is argued that China's economy grew rapidly not "in spite of," but "because of," weak property rights. ${ }^{9}$ China's own experience thus seems to suggest China could maintain rapid economic growth even if the legal system remains weak.

To gain a richer and deeper understanding of law in China's economic growth and answer whether China has to strengthen its legal system in order to sustain economic growth, this paper undertakes a case-study of China's stock market by examining its growth history and legal development. Similarly to the whole economy, the stock market in mainland China has grown to a substantial size since the opening of the Shanghai (SSE) and Shenzhen Stock Exchange (SZSE) in 1990, but the market remains peculiar, unruly, and dysfunctional. Currently, it faces a serious challenge to fulfil the tasks that are expected of it to support the real economy. Moreover, the stock market not only plays an important role in supporting the growth of the economy, but is also a window of it. As the economy continues to grow, commercial transactions would expand both in scale and scope, and become highly impersonal, just like investment and trading in a stock market. The stock market represents an advanced stage of development that the economy has to move to if China wishes to reach a high level of prosperity. Therefore, the stock market is a fitting case, an investigation of which would offer insight into the role of law in the growth of the whole economy and shed light on its prospect.

The following section provides a brief introduction to the history of the growth of China's stock market. Section 3 presents the development of the legal and regulatory system. Section 4 examines the role of law in different stages of the growth. Section 5 investigates why law does or does not strengthen, and explores fundamental causes for market growth. Last, a conclusion is drawn on the lessons that the stock market would tell about the whole economy.

\footnotetext{
2. Wall Street Journal (2012a); Wall Street Journal (2012b); Er-Rafia (2016); Cai (2017a).

3. New York Times (2009); Dam (2006), pp. 233-78; Xie (2014); Ji (2017).

4. Xinhua (2014).

5. Rheinstein (1954). See also North (1990), p. 54; Williamson (1985), p. 2; Williamson (1996), p. 332; Davis \& Trebilcock (2008).

6. Trebilcock \& Leng (2006); Davis \& Trebilcock, supra note 5.

7. Clarke et al. (2008), p. 376.

8. Allen et al. (2005).

9. Upham (2013), pp. 82-104.
} 


\section{A BRIEF HISTORY OF MARKET GROWTH}

The current stock market has its roots in the emergence of shareholding companies after the economic reform started in 1978. The first green shoots appeared in rural areas, ${ }^{10}$ but it was later in urban China that the shareholding system developed and stock markets emerged. From 1984, the attention of economic reform shifted to cities, and the focus was to revitalize ailing state-owned enterprises (SOEs). Local governments were allowed to experiment with the shareholding system as a pilot scheme for SOE reform. In 1987, the CPC proposed to separate the ownership and management of SOEs and to expand the shareholding experiment. ${ }^{11}$ Subsequently, a flurry of share issuances swept over the country. Markets for stock trading emerged spontaneously, as holders traded shares at places like street cornersso-called "kerb trading." 12 From 1986, state-owned banks started to offer over-the-counter (OTC) services for stock trading, and the OTC market opened in Shanghai in September 1986 by a local branch of the Industrial and Commercial Bank is commonly regarded as the first. ${ }^{13}$ But shares were unattractive and markets were lethargic, until a wave of "share fever" broke out in Shenzhen in 1990, igniting the enthusiasm of mainland Chinese for stock investment.

The Shanghai and the Shenzhen Stock Exchange started operation in December $1990 .{ }^{14}$ But the market was miniscule until early 1992, when Deng Xiaoping's "Southern Tour" sparked an explosion of economic activities across the country. Share prices skyrocketed and a new round of share issuance was triggered. Stocks were so popular that, on 9 August, more than one million people queued in the streets of Shenzhen to subscribe for shares, which turned into a riot in the evening when many of them failed to acquire a subscription form. ${ }^{15}$ Share prices dived, but recovered after Beijing expressed continuing support for its development and the Shanghai and Shenzhen governments instructed financial institutions to buy shares on the exchanges. ${ }^{16}$ But the excess let loose by Deng's campaign soon had its effect on the economy. Inflation rose rapidly and, by 1994 , reached a dangerous level of $24.1 \%{ }^{17}$ Forceful actions were taken to reign in the hyperinflation. Share prices then dropped from January 1993 until early 1996, and market growth slowed down. During this period, the number of listed companies increased from 13 in 1991 to 323 by the end of 1995, and funds raised via initial public offerings (IPOs) rose from RMB 0.1 billion in 1991 to RMB 18.5 billion in 1993, but decreased to RMB 4.2 billion in $1995 .^{18}$

By 1996, the macro economy had changed, the inflation rate had dropped, and interest rates were cut. Moreover, the government's attitude towards the stock market also changed. The previous SOE reform policies came to a dead end and the whole SOE sector recorded a net loss in the first quarter of $1996 .{ }^{19}$ SOEs were desperately in need of funding. Various

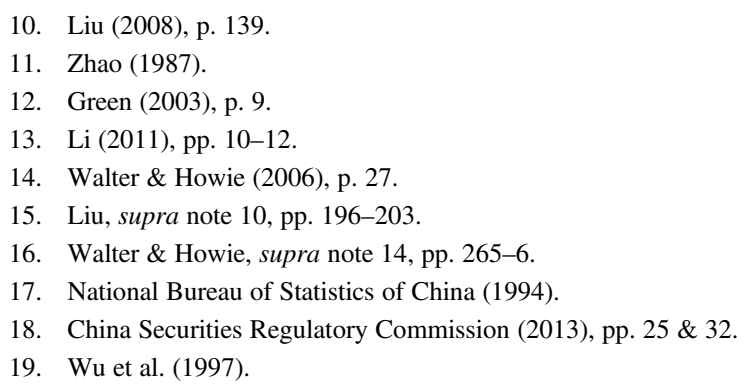


policies were adopted to stimulate the stock market so that SOEs could raise money on it. Share prices then rose steadily from January 1996. By December, the Shanghai Composite Index (SHCOMP) had more than doubled and the Shenzhen Composite Index (SZCOMP) more than quadrupled. ${ }^{20}$ Increasingly, Beijing became concerned and measures were introduced to cool down the market, but it forged ahead. Eventually, it was decided that drastic actions were needed and the People's Daily published an editorial, sounding harsh warning against "excessive speculation" and vowing to bring the market under control. ${ }^{21}$ Investors panicked and share prices plummeted. Shortly, the Asian Financial Crisis swept the region and China's economic growth decelerated considerably. The market became quiet, with share prices moving in a narrow range until May 1999. Again, IPO and listing had to be slowed down but, after this cycle of up and down, the number of listed companies increased to 851 by the end of 1998 and IPO funds reached RMB 65.2 billion in $1997 .^{22}$

In the 40 days from 19 May 1999, the SHCOMP jumped more than $65 \%$ and, by 14 June 2001, both the SHCOMP and SZCOMP had more than doubled. The number of listed companies increased to 1,160 by the end of 2001 and IPO funds reached a historical high of RMB 81.2 billion in $2000 .{ }^{23}$ Underpinning this boom were again changes in the macro economy and supportive government policy. By 1999, the Asian Financial Crisis had subsided and the Chinese economy stabilized. Exports picked up, as did the inward foreign direct investment (FDI); inflation became deflation and interest rates were cut on multiple occasions. On the other hand, the SOE reform strategy fundamentally changed and the stock market was no longer only seen as a source of finance, but also as a solution to the governance problems of SOEs. Large and medium-sized SOEs were decreed to diversify their ownership and increase equity finance. ${ }^{24}$ Corporatization and listing were established as the primary means of reform. Lastly, inspired by the "dot-com bubble" in the US, fraudsters in China fabricated various hi-tech stories and audaciously engaged in market manipulation. ${ }^{25}$ The market boom was also partly driven by fraud.

After reaching a historical high on 14 June 2001, the stock market entered into a bear market lasting for four and a half years, during which stock indices lost more than half and the market capitalization to GDP ratio decreased from $48 \%$ to $18 \%$. IPO was suspended three times and funds raised through IPO declined to RMB 5.7 billion in $2005 .^{26}$ The securities companies as a whole were in the red for four years. A series of shocking scandals were exposed, greatly shaking investors' confidence. The market was gripped by bitter debates triggered by a prominent economist's public denouncement of it as being "worse than a casino." 27 Another economist urged the government to "close down the market and start a new one from scratch." 28 The market slid to the brink of complete collapse. Again, various measures were adopted to prop up the market, but to no avail this time. As the crisis

20. Historical data of major stock indices are available at http://finance.sina.com.cn/stock/.

21. Renmin Ribao (1996).

22. China Securities Regulatory Commission, supra note 18, pp. 25 \& 32.

23. Ibid

24. Communist Party of China (1999).

25. For example, see Li, supra note 13; Ling \& Wang (2001).

26. China Securities Regulatory Commission, supra note 18, p. 32.

27. McGregor (2001); Kuhn (2001).

28. Pan (2001). 
intensified, the government realized that more needed to be done. A campaign was launched to crack down on market fraud and instil a degree of law and order, and investor protection was strengthened. Eventually, the market recovered in 2006 and experienced an enormous boom in 2007. By October 2007, the SHCOMP was nearly sixfold the level at the beginning of 2006. The number of listed companies increased to 1,550 by the end of 2007 and major SOEs, the "national champions," including the giant state-owned commercial banks, were listed. Total market capitalization rose to the second in the world and IPOs' funds soared to RMB 477 billion in 2007-by far the highest in the world. ${ }^{29}$

However, the boom was short-lived and shares prices started to drop from October 2007 and, as the global financial crisis intensified, embarked on a free fall. By October 2008, the SHCOMP had sunk by almost $75 \%$. Again, various actions were taken to prop up the market and, facing a looming economic crisis, the country's leadership made a dramatic decision to spend RMB 4 trillion to stimulate the economy. ${ }^{30}$ The floodgate for bank lending was also opened and new loans in 2009 almost doubled the previous year's amount. ${ }^{31}$ The stock market responded fiercely and share prices shot up. IPOs resumed and a new board-the ChiNext — was opened in Shenzhen in 2009 to list growth companies. Funds raised in 2010 even surpassed the boom year of 2007. ${ }^{32}$ But the effect of stimulation was brief. The market lost steam after August 2009 and went on a downward trend from 2010. In May 2012, the government instigated a "stimulus 2.0,"33 but the impact was negligible. As share prices continuously fell, the market drifted into another crisis. IPO was suspended for more than one year until another cycle of boom and bust started in $2014 .^{34}$

In an aim to alleviate heavy debt burdens of corporate China as well as to facilitate entrepreneurship and indigenous innovation, the state machinery under the new leadership of Xi Jinping was mobilized from 2013 to stimulate the market in order for more companies to access it. The China Securities Regulatory Commission (CSRC) relaxed regulation and prioritized growth over law enforcement; the media controlled by the CPC increasingly published bullish commentaries on the prospect of the market and senior government officials including the governor of the People's Bank (PBOC) gave optimistic talks ${ }^{35}$; interest rates and bank reserve ratios were cut. Subsequently, the market staged a rally from July 2014 and, by June 2015, the SHCOMP had risen by more than 250\%. Investors flocked in and borrowed money, especially margin financing exploded. The number of listed companies increased to 2,797 by the end of May 2015. ${ }^{36}$ However, from early June 2015, share prices nosedived and the SHCOMP lost more than $40 \%$ in just over three months. The government panicked and desperate attempts were made to rescue the market. The so-called "national bull market" became a disaster. Instead of allowing more companies to access the market, IPOs had to suspend again and hundreds of companies queuing for an IPO had to

\footnotetext{
29. China Securities Regulatory Commission, supra note 18, p. 32.

30. Xinhua (2008).

31. Xinhua (2010).

32. China Securities Regulatory Commission, supra note 18, p. 32.

33. Zhang \& Huang (2012).

34. Rabinovitch (2013).

35. Guilford (2015).

36. China Securities Regulatory Commission (2015a).
} 
wait for more time. The plan to introduce a US-styled registration-based IPO system to allow more companies to access the market had to be shelved.

The market rose from October 2015 in response to the desperate rescue actions taken by the government. As a result of these actions, a "national team" consisting of securities companies, investment funds, and other state-owned financial institutions was formed, which actively traded shares on the stock exchanges under the direction of the CSRC to smooth out volatility. ${ }^{37}$ The government gained even more control over the market and acquired an additional tool to make sure that stock indexes move in the range that it deems appropriate. However, the introduction of the so-called "circuit breakers" at the beginning of 2016, which was supposed to "protect investors and calm the market," triggered panic selling, and trading was halted in two days in the first four trading days of the year. The CSRC announced it would scrap the system on 7 January, by which time the SHCOMP had already lost more than $10 \%$ in just four days. ${ }^{38}$ In the following periods, the market moved in a narrow range with reduced volatility. But the prices of small cap stocks continuously dropped, while the index for large cap stocks moved upward. At the end of 2017, the index for the ChiNex market was even lower than the bottom line reached during the 2015 crisis, whereas the SSE 50 Index, which comprises 50 large blue-chip companies, climbed about one-third during the same period. ${ }^{39}$ This divergence is due to larger bubbles previously formed in small cap stocks and the government's actions to guide investment in blue-chip companies. As the market stabilized, IPO resumed and funds raised via IPOs amounted to RMB 149.6 billion and RMB 235 billion in 2016 and 2017, respectively. ${ }^{40}$

\section{THE DEVELOPMENT OF LAW}

Although shareholding companies appeared from the very beginning of the economic reform and markets for stock trading emerged later, there were few corporate and securities laws before 1992. It was not until 1984, when the Shanghai government ratified a document drafted by the PBOC Shanghai branch, that the first such type of legislation came about. ${ }^{41}$ At the national level, the first was a 1985 document issued by the State Administration for Industry and Commerce permitting company registration. ${ }^{42}$ But, throughout this period, the national legislature, the National People's Congress (NPC), and its Standing Committee (NPCSC), as well as the State Council, did not enact any corporate or securities laws. The PBOC in Beijing, which was designated as the market regulator in 1986, promulgated only one major piece of relevant legislation during this period. ${ }^{43}$ Since shareholding companies and stock markets sprang up locally and local governments were the experimenters and promoters, rules were adopted by some local governments to guide experiments. But these rules were rudimentary at best. For instance, the first legislation by the Shanghai

\footnotetext{
37. Zhang (2017).

38. BBC (2016).

39. $\mathrm{Yu}(2017)$.

40. KPMG (2017).

41. Shanghai Municipal Government (1984).

42. State Administration for Industry and Commerce (1985).

43. People's Bank of China (1990).
} 
government has only eight articles altogether. Investor protection was not yet on the agenda and shareholders' rights were barely mentioned in these local instruments.

Following the "share fever" triggered by Deng's "Southern Tour" in early 1992, a number of regulations were adopted by the central government. But it was after the riot in Shenzhen that legislation accelerated and a specialized regulatory body was set up. The top leadership in Beijing realized the risk that a chaotic market would cause and the importance of laws and regulations for an orderly market. ${ }^{44}$ In October 1992, the State Council announced the establishment of a new regulatory system, consisting of the State Council Securities Committee (SCSC) and the CSRC. The SCSC would be a meeting system of senior government officials, responsible for policy formulation, co-ordination, and organizing laws and regulations drafting, while the CSRC would be the executive office of the SCSC. ${ }^{45}$

After the SCSC and CSRC were set up, legislation was passed at great pace. First, the Interim Regulations on the Administration of Share Issuance and Trading was adopted in April $1993{ }^{46}$ This was a pillar of the legal system until the Securities Law was enacted in 1998. It was comprehensive, covering all the relevant issues concerning stock issuance and trading. To implement this legislation, detailed rules on information disclosure and antisecurities fraud were issued by the SCSC and CSRC in $1993 .{ }^{47}$ The SCSC and CSRC also promulgated a large number of regulations and rules to govern other issues, such as the organization and management of the stock exchanges; the regulation of securities companies and their businesses such as underwriting, proprietary trading, investment consulting, and fund management; the qualification and disqualification of securities practitioners; and so on. Last, abundant numbers of normative documents, decrees, notices, etc. were issued, dealing with ad hoc issues, responding to changes or providing operational guidance. The total number of relevant laws, regulations, and rules had exceeded 250 by $1998 .^{48}$

In December 1993, the Company Law was adopted by the NPCSC. Although it was criticized for its conservatism left over from the era of planned economy, ${ }^{49}$ a legal footing for company formation and operation was finally in place. While other laws and regulations were passed with high efficiency, the adoption of the Securities Law was long delayed due to bitter disputes on some key issues and a turf war between two departments of the NPCSC. ${ }^{50}$ The law was eventually passed in December 1998, after the top leadership intervened in the wake of the Asian Financial Crisis, and took effect from 1 July 1999. Overall, the law was rigid and restrictive, reflecting the government's approach of heavy regulation and control in the face of wild speculation and rampant fraud in the market. ${ }^{51}$ Nevertheless, the enactment of the Securities Law marked the completion of the establishment of a basic legal framework governing the stock market. On criminal legislation, the first was a Decision passed by the NPCSC in 1995 to punish violations of the Company Law as well as fraudulent or unapproved public offerings and false disclosure of financial

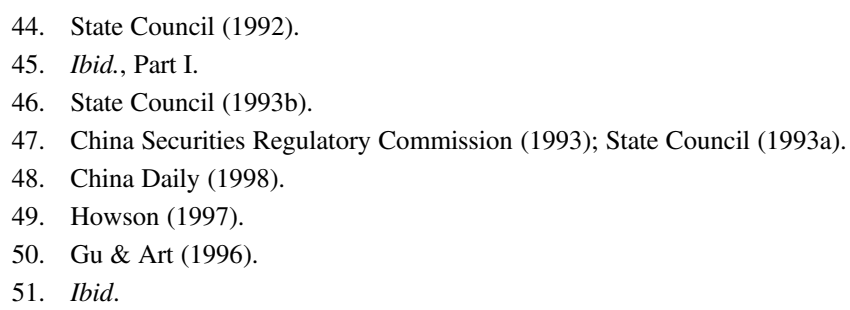


information by listed companies. ${ }^{52}$ The contents of the Decision were included in the Criminal Law when it was codified in 1997. The 1997 codification also added punishments for insider trading, divulging inside information, fabricating and spreading false information, and manipulating share prices by way of trading. ${ }^{53}$

Despite the establishment of the SCSC and CSRC in 1992, the regulatory system remained fragmented. The regulatory power was shared by other ministries such as the State Planning Commission, the PBOC, and the Ministry of Finance. The Shanghai and Shenzhen Stock Exchanges were under the control of the respective governments. Moreover, following the central government's practice, provinces and cities set up their own regulators, over which the CSRC had no jurisdiction. The CSRC was weak, isolated in Beijing, and lacked authority. It was a series of scandals that led to changes. The " 327 government bond futures" scandal $^{54}$ and Shanghai and Shenzhen governments' using local securities companies and bank money to manipulate share prices ${ }^{55}$ prompted Beijing to strip the two governments of the control of the stock exchanges, which was achieved in August 1997. Further changes were made after the Asian Financial Crisis. In November 1997, the CPC decided to reform the regulatory system. ${ }^{56}$ The SCSC was abolished and the CSRC was upgraded to the rank of a full ministry. The PBOC's power of licensing and supervising securities institutions and investment funds was transferred to the CSRC. The quota system for share issues was abolished so that the State Planning Commission was no longer involved in the regulation of the stock market. Existing local regulators were taken over by the CSRC and new ones were set up across the country. By July 1999, a unified and centralized regulatory system had been established. The CSRC became a powerful market regulator with physical presence across the country.

After the new system was established, the CSRC faced the serious challenge of widespread fraud. Corporate funds were routinely misappropriated, information falsification and false disclosure were normal practice, and market manipulators engaged in audacious scams. 2000 and 2001 are remembered in the history of China's stock market for the revelation of a series of outrageous scandals. ${ }^{57}$ The CSRC was forced to launch a campaign to crack down on fraud. As the stock indexes dropped further and the market was in an existential crisis, the CSRC was pressured to strengthen law enforcement, which was helped by the regulatory overhaul with increased resources. In the meantime, laws and regulations were amended and new rules were adopted to provide more protection to investors. In August 2001, the CSRC decreed that at least one-third of directors of a listed company should be independent. ${ }^{58}$ In January 2002, a corporate governance code for listed companies was adopted. ${ }^{59}$ As scandals continued and the crisis worsened, a large number of rules, documents, and ad hoc

52. NPCSC (1995).

53. NPC (1997), Arts 180, 181, \& 182.

54. It is a scandal of trading on inside information and manipulating prices of treasury bond futures, which led to the bankruptcy of Wanguo, then the most prominent securities company, and the closure of the market for treasury bond futures for 18 years. See also Green, supra note 12, pp. 19-21.

55. Kan (2010), pp. 155-72.

56. CPC \& State Council (1997), Section 12.

57. See infra discussion in Section 4.

58. China Securities Regulatory Commission (2001).

59. China Securities Regulatory Commission (2002). 
notices were issued to address such issues as related-party transactions, use of funds by listed companies, takeover and asset restructuring, independence of listed companies from their controlling shareholder, and so on. In December 2004, the CSRC issued a regulation specifically for minority-investor protection. ${ }^{60}$ In 2005, the Company Law and Securities Law were amended extensively to offer shareholders more legal rights and the CSRC more enforcement power. In 2006, the Criminal Law was revised to close loopholes and increase corporate managers' criminal liability. Subsequently, rules previously adopted by the CSRC were updated in accordance with the revised primary statutes and more operational rules were issued by the CSRC.

Consequently, by 2006, investor protection had improved considerably. Major deficiencies in legislation were corrected and investors offered more legal rights. Regulations, rules, and normative documents for investor protection were abundant. Enforcement was also strengthened, witnessed by both the input of resources and the output of enforcement activities. In the following years, legislation further multiplied and the total number exceeded 1,200 by $2013 .^{61}$ The enforcement system was further overhauled and the number of enforcement personnel at the CSRC increased. However, the output of enforcement activities stayed at the same level until the 2015 crisis and the improvement of law and order had not been sustained. Fraud became widespread again during the 2014-15 bubble, and another enforcement campaign launched after the crisis led to a twofold rise in the number of individuals and institutions penalized by the CSRC in $2015 .^{62}$

\section{THE ROLE OF LAW IN MARKET GROWTH}

China has built from scratch a complex legal and regulatory system governing the stock market. It consists of a large amount of primary and secondary legislation as well as numerous rules, decrees, orders, notices, normative documents, etc. The CSRC has established a sophisticated enforcement system divided into investigative and adjudicative functionaries, central and local, and coordinative and front-line enforcement bureaus. The Ministry of Public Security has set up a specialized bureau with six local divisions for criminal investigation. ${ }^{63}$ In addition, the SSE and SZSE also have their surveillance, supervision, and enforcement task force. Has this legal and regulatory system played a role in the growth of China's stock market? In economic development, law plays a protective as well as a non-protective role such as co-ordinating, signalling, credibility enhancing, and providing rules for operations. ${ }^{64}$ As far as the non-protective role is concerned, there is no doubt that the legal system in China has the same functions as that of other countries. Indeed, it is suggested that the non-protective function of law is more prominent in centralized China, especially in the early stages of the economic development. ${ }^{65}$ What is controversial is the protective role of law in China's economic growth. Therefore, this section focuses on the

\footnotetext{
60. China Securities Regulatory Commission (2004).

61. Xiao (2013).

62. China Securities Regulatory Commission (2016).

63. 21 Shiji Jingji Baodao (2003).

64. Milhaupt \& Pistor (2008), pp. 31-8; Funk (1972).

65. Milhaupt \& Pistor, supra note 64, pp. 7 \& 34.
} 
function of law for investor protection and examines whether laws on investor protection have played a role in the growth of China's stock market.

China experienced bouts of "share fever," one of which caused a riot in 1992, even before basic laws for investor protection were in place. Between 1992 and mid-2001, when the serious crisis started, the market grew steadily and the number of listed companies increased from 13 in 1991 to 1,160 by the end of 2001. On the other hand, although laws were adopted after 1992 and the basic legal framework had been established by 1998, laws on investor protection were rudimentary. For example, the Company Law 1993 was seriously defective and legal rights and remedies that are critical for shareholder protection were glaringly absent. ${ }^{66}$ Even these rudimentary laws were not enforced. The CSRC did not have an enforcement department until 1996 and, once established in 1996, the department had no more than 33 staff members until 2001. There were few enforcement activities. For instance, the annual figure of market manipulation and insider-trading cases sanctioned by the CSRC was in single digits between 1993 and $2001{ }^{67}$ Penalties entered into by either the CSRC or the two stock exchanges in the forms of warning, public censure, or fines against information misrepresentation were also in single figures every year before $2001 .^{68}$ As a result, market fraud was widespread and blatant. Even the Shanghai and Shenzhen governments organized manipulation to boost stock trading and the two stock exchanges offered support. By the end of the 1990s and early 2000s market manipulation, false disclosure, and misappropriation of listed companies' funds by their controlling shareholders had become systemic. Misappropriation happened to 737 listed companies out of a total of 1,287 at the end of 2003, and the total amount of misappropriated funds reached RMB 113.2 billion, while the total profits of listed companies in that year were RMB 178.2 billion. ${ }^{69}$ For false disclosure, one study estimated that $72 \%$ of listed companies engaged in such misconduct $^{70}$; for market manipulation, even the CSRC estimated that $80 \%$ stocks were manipulated in 2001. ${ }^{71}$ Observers of the market summarized that "China's stock market is a notoriously corrupt place. Securities firms, investment funds, finance companies and rich individuals all manipulate prices and spread prodigious amounts of false information"72, "insider trading and manipulation of the market have been conducted almost half-openly",73 and were "something of an open secret." "74 Basically, the market was in a state of "law without order." It was indeed "worse than a casino." Clearly, law was irrelevant and investor protection did not play a role in the growth of the market during this period.

The market then fell into an existential crisis from mid-2001 until 2005. Why did this happen while China's macro economy was at its best shape? Many so-called "opinion leaders" blamed the State Council's decision in June 2001 to sell down state shares on the exchanges, which increased the supply of shares. ${ }^{75}$ It is likely that the market fell in 2001

\footnotetext{
66. Howson, supra note 49.

67. Shi \& Jiang (2005).

68. Luo (2005).

69. Wang (2005).

70. Green, supra note 12, p. 137.

71. Wang (2012).

72. Green, supra note 12 , p. 164.

73. Zhang (1999).

74. Walter \& Howie, supra note 14, p. 64.

75. Lu (2008), pp. 36-9.
} 
because the bubble became too big and a large number of companies made a loss. ${ }^{76}$ However, while statistically hard to prove, qualitative evidence strongly suggested that market fraud caused by weak investor protection was also responsible for the crisis. First, the revelation of fraud led to sharp falls in the share prices and wiped out substantial amounts of the market value of companies involved. For example, the price of Yi'an Keji, a listed company involved in a notorious market-manipulation scam, ${ }^{77}$ plummeted from its highest point of RMB 126.31 on 17 February 2000 to less than RMB 10 in January $2002 .^{78}$ The share price of Yinguangxia, infamous for forging export contracts and receipts to fabricate profits, ${ }^{79}$ plunged from more than RMB 33 in August 2001 to just over RMB 2 at the end of January 2002 and reached the $10 \%$ daily price movement limit for 15 days continuously. In April 2004, Delong Group, a private conglomerate that acquired a web of financial institutions and bought control of three listed companies for manipulation, crumbled, wiping out RMB 20 billion of market value in ten trading days. ${ }^{80}$ These cases showed that a scandal had a devastating effect on the share price and market value of a company. One study identified 212 scandals in the stock market between 1997 and 2005. ${ }^{81}$ Hence, the effect on the overall market performance was substantial. They were directly responsible for the fall of stock indices and loss of market capitalization during this period.

A scandal not only affected the involved stock, but might shake the whole market. For example, after the fraud of Yinguangxia was publicized on Sunday 5 August 2001, the Component Index of Shenzhen where the company was listed lost $4.38 \%$ on the following Monday, whereas the index moved narrowly during the previous trading week. ${ }^{82}$ It was very possible that the sudden plunge of the market might be caused by the revelation of the scandal. Since there were so many scandals, the market was rocked repeatedly and share prices were continually hit. It is possible that, eventually, investors found share investment too risky and decided to leave the market. The Chinese stock market was not just "worse than a casino," but also had a reputation as "a minefield full of traps"- one trip and an investor would be "blasted to pieces." $"$ Faced with such a high and dangerous risk, investors understandably withdrew from the market. That is why, in 2005 , only $33 \%$ of all the trading accounts on the SZSE held stocks. ${ }^{84}$ The experience of the stock market during this period thus demonstrates that law is essential for sustaining market growth. Fraud caused by weak investor protection not only had devastating effects on market performance, but also eroded investors' confidence in investing in the market, both of which inhibited market growth.

The recovery of the market in 2006 led to an enormous boom. The market reached a new height and major state-owned "national champions" were listed. Again, there are different explanations for the revival, but it is noticeable that, by 2006, the fraud that had once plagued the market had been curbed and a degree of law and order established in the market.

\footnotetext{
76. Xu (2001).

77. $\mathrm{Li}(2001)$.

78. Historical daily data of the price of individual stocks were available at http://finance.sina.com.cn/stock/.

79. Ling \& Wang, supra note 25.

80. Ling et al. (2006).

81. Hung et al. (2011).

82. Data are available from http://finance.sina.com.cn/stock/.

83. Pi (2001).

84. China Securities Regulatory Commission (2008), p. 112.
} 
A campaign to force misappropriated funds of listed companies to be returned was well underway after the State Council's intervention and the threat of criminal sanctions. In the meantime, laws on investor protection had been strengthened and enforcement considerably improved. Major statutes were revised and multiple new laws, regulations, and rules were adopted to provide more protection for small investors. As a result, minority shareholders' legal rights had been enhanced significantly and various indicators suggested that, by 2006, shareholders' rights in China were comparable to or even more generous than those of major developed economies. ${ }^{85}$ Not only were investors offered more legal rights, but changes made in other areas also enhanced their protection. For example, to prevent securities companies from misappropriating their clients' funds, the CSRC decreed in 2004 that investors' funds be deposited in commercial banks rather than with securities companies themselves. The Securities Law 2005 formally stipulated this requirement. ${ }^{86}$ Since then, securities companies' misappropriating their clients' funds has disappeared. The same law provided that one investor could only open one trading account and the name of the trading account and the investor's name should be identical. ${ }^{87}$ As a result, it has been much more difficult for manipulators to corner a stock by using multiple trading accounts and hide the fraud. The Securities Law 2005 also greatly increased the use of the penalties of banning market entry, disqualification, and suspending or revoking business licences. ${ }^{88}$ These penalties would have a stronger deterrence effect than the administrative fine, which in most cases is a small amount of RMB 300,000 for individuals and RMB 600,000 for legal persons at most. The revision of the Criminal Law in 2006 made directors and other senior managers of listed companies or the controlling shareholders criminally liable for misappropriation even if they gained no personal benefit. ${ }^{89}$

Not only were laws adopted to offer investors more legal rights, but law enforcement had also improved, which could be seen from both the input of resources and the output of enforcement activities. As for resources, first, the CSRC's enforcement department branched out of Beijing after taking over local regulators in 1999. In 2001, the enforcement unit of nine major local regulators was upgraded to become a bureau directly under the CSRC's control. ${ }^{90}$ In the same year, a specialized enforcement bureau for investigating insider trading and market manipulation was set up at the CSRC's headquarters in Beijing and the total number of enforcement staff at the headquarters increased by 32 to nearly 60 . The total number of enforcement staff in the whole system increased to more than $270 .{ }^{91}$ A specialized bureau for investigating securities crimes with six local divisions was established in 2002 by the Ministry of Public Security. ${ }^{92}$ In 2007, the CSRC's enforcement system was overhauled again. Investigation and adjudication were separated and a new department was set up solely for adjudication. One hundred and seventy employees-nearly three times the previous

\footnotetext{
85. Armour et al. (2009); Shleifer et al. (2008)

86. NPCSC (2005), Art. 139.

87. Ibid., Art. 166.

88. Ibid., Art. 233.

89. NPCSC (2006), Art. 9.

90. Wang (2009), p. 65.

91. Ibid.

92. 21 Shiji Jingji Baodao, supra note 63.
} 
figure-were added to the investigation departments in Beijing and 110 at the local level. The total number of staff for investigation increased to about 600 - nearly 20 times the figure in 1999. ${ }^{93}$ In addition, the CSRC was offered more investigative power by the Securities Law 2005, including the power to inspect and freeze bank accounts and securities trading accounts; to seize assets, property and evidence; and to restrict securities trading. ${ }^{94}$ Furthermore, CSRC's capacity to detect fraud was also enhanced. For example, local regulators were required to undertake regular inspections of listed companies and securities institutions; both Shanghai and Shenzhen Stock Exchanges set up a surveillance department and sophisticated computer software was installed to monitor abnormal trading and price movements in real time. This surveillance system is now a key instrument for detecting insider trading and market manipulation.

From the output perspective, various studies found that enforcement activities increased markedly from 2001. For example, data collected by Pistor and $\mathrm{Xu}$ (2005) indicated that sanctions by the regulators and stock exchanges more than quadrupled in 2001 from the previous year's figure. Luo et al. (2005), in their study of law enforcement against listed companies for information misrepresentation, found that the sanctions by the CSRC and stock exchanges more than doubled in 2000 and doubled again in 2001. While it was argued that the number of enforcement actions was still too low in light of the total number of listed companies, ${ }^{95}$ there is no doubt that enforcement intensified considerably after 2000. Enforcement activities increased further after 2005 and the total number of sanctions by the CSRC and the two stock exchanges has since exceeded 100 every year.

As a result of all these efforts to enhance investor protection, the scale and seriousness of market fraud had decreased significantly by 2006 . The once-ubiquitous stock cornering and the audacious fraud of acquiring listed companies for manipulation had largely disappeared, as had the misappropriation of clients' funds and stocks by securities companies. Second, although there were still news reports about controlling shareholders stealing listed companies' funds, the days when this happened to 737 companies out of a total of 1,287 had gone. Third, information misrepresentation was still a serious problem. Companies still invented profits and a large number still engaged in other types of misrepresentation, indicated by the large number of sanctions handed out by the CSRC and stock exchanges. However, compared to the days when $72 \%$ of listed companies were estimated to have engaged in false disclosure, there was no doubt that the situation had improved. All in all, the scale and seriousness of market fraud had decreased considerably by 2006 , which could be a reason why the market revived. Without such improvement, it is reasonable to question whether the market could resurge in 2006 and survive the 2008 crash and the prolonged bear market between 2010 and 2014.

To conclude, while the stock market grew steadily even though laws for investor protection were absent or not enforced before 2001, it fell into an existential crisis from mid-2001 and pervasive fraud caused by weak investor protection was no doubt an explanation. The market revived in 2006 after investor protection had greatly improved, which meant that market revival was based on improvement of investor protection. The experience of the stock market during

93. Xin Jing Bao (2008).

94. NPCSC, supra note 86, Art. 180.

95. Pistor \& Xu (2005); Luo, supra note 68; Clarke (2010). 
this period thus demonstrates that law is necessary for market growth. It not only played nonprotective roles, but also offered investors protection to sustain market growth.

\section{FUNDAMENTAL CAUSES FOR MARKET GROWTH}

\subsection{Causes for the Improvement of Law}

The experience of the stock market clearly demonstrated that, while law played a role in sustaining growth, the trajectory of development is growth first followed by law. The shareholding system and the stock market emerged and grew in the 1980s when a basic legal and regulatory framework was absent and investor protection was none. While the CSRC was set up and laws were quickly put in place after 1992, they were rudimentary for investor protection and basically unenforced until the severe crisis broke out in the early 2000s. The government's decision in 1992 to establish a legal and regulatory system was prompted by the market bubble and the "riot" in Shenzhen, by which point waves of "share fever" had already occurred. The motivation was to bring order to the rapidly growing market. Similarly, the improvement of investor protection and establishing a degree of law and order were caused by the crisis in the early 2000s, by which time the market had already grown to a substantial size with more than 1,000 listed companies and tens of millions of investors. These investors became a powerful political constituency and their anger, triggered by the exposure of a series of grotesque frauds and the fall of share prices, put enormous pressure on the government. Moreover, as the number of investors grew, the demand for financial and stock-market information increased. In response, financial media and news reports proliferated, helping to inform investors and enabling them to express views with stronger collective voices. The government was motivated by another consideration to tackle fraud and enhance investor protection. The stock market became a critical institution by the early 2000s after it had grown to a substantial scale. It was not only important for SOE finance and reform, but also seen as crucial for indigenous innovation, entrepreneurship, and reducing risk in the financial system. ${ }^{96}$ However, with the decline of the market, the implementation of all these strategies had to be put on hold. To revive the market, it was plain that fraud had to be curtailed and investors offered more protections.

If the improvement of law is caused by market growth, it needs to be asked why the market grew in the first place. Fundamentally, political and ideological liberalization led to the growth. First, the shareholding system and stock markets were allowed to emerge in the 1980s, just because the ultra-leftist ideology that regarded capital as exploitative and evil was gradually abandoned and the politics barring private ownership of production means was relaxed. Speeches by Deng Xiaoping during his "Southern Tour" in 1992 further broke down the leftist dogmas that the market was incompatible with socialism. The political stigma attached to the shareholding system and the stock market was then removed, and the ideological and political obstacles for stock-market development cleared. Second, political and ideological liberalization led to economic reform and growth, which underpinned the growth of the stock market. A demand for alternative sources of SOE financing was created, after funding from government budgets was cut off as a result of SOE reform in the late 1980s. As ideology and politics

96. State Council (2004). 
regarding SOEs were further liberalized after 1992, the stock market was not just a source of SOE financing, but also became a venue for reforming the governance of SOEs, adding more economic rationales for developing the market. On the other hand, as the economy grew rapidly, so did household disposable incomes and savings, providing sufficient supply to meet the demand for finance. ${ }^{97}$ In 1997 , the CPC further liberalized its ideology and policy towards private ownership, ${ }^{98}$ which spurred the phenomenal growth of the private sector and generated a new demand for finance. By the early 2000s, meeting the financing demand of private enterprises became an urgent issue, hence the opening of the Small and Medium-Sized Enterprise Board in 2004 and the ChiNext in 2009. By the end of 2011, more than half of the number of listed companies were private enterprises. ${ }^{99}$

In conclusion, while law played a role in supporting the market growth, the establishment of the legal and regulatory system and the improvement of investor protection were caused by market growth, which was in turn caused by ideological and political liberalization. Ideological and political liberalization was fundamental, because it brought market growth in the first place and market growth in turn underscored the improvement of law.

\subsection{Barriers for Market Growth}

Although the stock market in China grew steadily and has become the second largest in the world in market capitalization, it did not reach its full potential and meet the financing need of the economy. Before 2001, IPOs and listing were strictly rationed, with an annual quota of the total number of companies that were allowed to list and shares to issue. Many companies, including the most successful ones such as Alibaba and Tencent, had to opt to list on overseas markets. Since 2001, companies have had to queue to be approved by the CSRC for an IPO. Even after having been approved, the timing of the IPO and listing is determined by the CSRC. ${ }^{100}$ The long-established practice is that the CSRC controls the IPO pace according to market conditions. When the market is hot, approval is loosened and the pace quickens; when it is cold, approval is tightened and the pace is slowed down or IPO is completely suspended, which has happened many times. The number of companies queuing for an IPO amounts to hundreds all the time in recent years, meaning years of waiting. On the other hand, China has had an exceedingly high saving rate. More than RMB 150 trillion is now deposited in banks and the size of China's shadow banking had grown to USD 8.5 trillion by 2017. ${ }^{101}$ Ever since the early 2000s, the Chinese government has adopted a strategy of developing the stock market to support the real economy and reduce risk in the financial system, but this has not been achieved as it wishes, as testified by the 2015 crisis.

Why does the Chinese government have to tightly control IPOs? Why do companies have to queue for years for an IPO while more than RMB 100 trillion is deposited in banks? Fundamentally, this is because the stock market produces very low returns for investors. Research reveals that, between 1992 and 2013, the return of the SHCOMP stocks was

97. For example, household bank deposits increased almost tenfold between 1980 and 1988. See NBSC (1980); NBSC (1988).

98. Jiang (1997).

99. CAPCO (2012), Part III.

100. China Securities Regulatory Commission (2015b).

101. Bloomberg (2017). 
slightly above one, meaning that RMB 1 invested in a value-weighted portfolio of SHCOMP stocks in 1992 would virtually yield a real return of zero by 2013; between 2000 and 2014, RMB 1 invested in a weighted portfolio of stocks listed in Shanghai and Shenzhen would decrease to RMB 0.94 in real terms. ${ }^{102}$ The dismal return of China's stock market is substantiated by the poor performance of dividend payouts. In the 1990s, few companies paid cash dividends. Even by 1999, 59\% of companies did not pay any kind of dividends (cash or bonus shares). ${ }^{103}$ Overall, it is found that the average annual dividend/price ratio of the mainland market was just over $0.75 \%$ between 1990 and 2010 - the worst by a long way among the 12 major markets of both emerging and developed economies. ${ }^{104}$ Because of the fall of share prices and the CSRC's pressure on listed companies to pay more, the dividend yield increased to $1.04 \%$ in $2009,1.14 \%$ in 2010 , and $1.82 \%$ in 2011 . It was announced by the CSRC in 2012 that the average dividend yield of the 300 blue-chip companies reached $2.34 \%$ in 2011, exceeding that of S\&P 500 stocks. ${ }^{105}$ The CSRC thus proclaimed that China's stock market had a value for long-term investment. But this claim is misleading. The risk-free interest rate was much higher in China. Even the government-set one-year deposit rate was above $3 \%$ in 2012, while the yield of one-year treasury bills in the US was lower than $0.5 \%{ }^{106}$ The market-based interest rates in China were even higher than the official ones. For example, the so-called "wealth management products" were popular among! Chinese investors and even the safest deposit-equivalent products originated by banks yielded around 5\% annually. ${ }^{107}$ It was misleading to compare dividend yields without considering the risk-free interest rates and the former is still considerably lower than the latter in China. The low dividends are not due to companies retaining profits for business expansion. Most companies paid no or little dividend, simply because they made no or little profit.

The low return of the market is underscored by the low profitability of the listed companies. Listed companies were described as "a capital-destroying machine" in the 1990s, and abundant capital raised from the market were wasted or simply disappeared. ${ }^{108}$ Profits created by these companies were lower than the opportunity cost of the equity capital they owned. ${ }^{109}$ The average ROE (return over equity) of listed companies published by the CSRC was $7.63 \%$ in $2000^{110}$-lower than that of non-listed companies and much lower than the $19.1 \%$ of the largest 1,000 listed companies from developed countries and $14.62 \%$ of the largest 200 companies from emerging markets. ${ }^{111}$ The ROE decreased further to $5.35 \%$ and the ROA (return over asset) was only $3.02 \%$ in 2001, while the official interest rate for one-year bank loans was

102. Allen et al. (2017).

103. Green, supra note 12, p. 131. Most of the companies paid bonus shares, which is only a change in book-keeping but does not offer shareholders real benefits.

104. He (2012).

105. Xu (2012).

106. Historical interest rate data for China can be found in China Statistical Yearbook (various years), available at http://www.stats.gov.cn/english/statisticaldata/AnnualData/, and historical treasury yield data for the US are available at www.treasury.gov/.

107. Zhang (2013), p. 116.

108. Green, supra note 12, p. 125.

109. Liu \& Sun (2005).

110. China Securities Regulatory Commission, supra note 18, pp. 282-3.

111. Hu (2003), pp. 3-6. 
$5.85 \%{ }^{112}$ The ROE increased from 2003, exceeding $10 \%$ in 2006 and reaching the all-time high of $14.7 \%$ in $2007 .{ }^{113}$ It then crashed in 2008, recovered in 2009, but dropped again from 2011, staying at $9.63 \%$ in $2016 .{ }^{114}$ Other research suggests that the ROE of listed companies is actually much lower than the CSRC figure. One study found that the average ROE of Chinese companies was only $7.83 \%$ in 2010 , while the figure of listed companies in the US was $10.71 \%{ }^{115}$ Another study revealed that the ROE was $11.14 \%$ in $2010,9.85 \%$ in 2011 , and $7.6 \%$ in 2012, and the median ROA was only $5.58 \%$ in 2012-again lower than the official interest rate for one-year bank loans. ${ }^{116}$

Ample evidence demonstrates that the profitability of listed companies as a whole is low and the stock market produces little return for investors, which explains the market's limited capacity to allow companies to raise funds and become listed, and why the government has to tightly control IPOs. For a long time, China's stock market has been in a bubble and the government uses IPO control to limit the supply of stocks to the market in order to maintain high share prices that are not matched by corporate profitability. Why is the profitability of listed companies low? First, the dominance over the market by inefficient SOEs surely reduced the profitability. China's stock market has long been dominated by SOEs. Although the number of listed SOEs had decreased to $47 \%$ of the total by the end of 2011, they still accounted for $90 \%$ of the total assets, $86 \%$ of the total revenues and profits, and $74 \%$ of the total market capitalization. ${ }^{117}$ Listing was supposed to improve SOEs' governance, but serious problems remain. SOEs have been riddled with endemic corruption, excessive wastes, and chronicle mismanagement. ${ }^{118}$ In such a state of governance, how can listed SOEs perform well in profitability? Second, it is surprising that listed private companies were even less profitable. One study found that, between 2002 and 2006, the ROE of private companies was lower than that of listed SOEs, in 2005 being $-1.4 \%$ as against $8.39 \%$ for SOEs. ${ }^{119}$ By 2011, the ROE for private companies was $12.12 \%$ - still lower than SOEs' figure of $14.51 \% .{ }^{120}$ Why does this occur? As of the end of $2006,62.47 \%$ of the listed private companies were from the manufacturing sector with excessive competition and tight profit margins, while SOEs dominated the lucrative sectors such as finance, communications, public utilities, infrastructure, and natural-resource exploitation. ${ }^{121}$ It is clear that, due to the entry barrier to the lucrative sectors, the profitability of private companies is low and the profitability performance of listed companies as a whole suffers. Third, low profitability is also caused by the difficult business environment with numerous bureaucracies and predatory financial burdens, ${ }^{122}$ as well as the fact that low-end industrial and service companies with tiny profit margins comprise the majority of listed companies in China. ${ }^{123}$

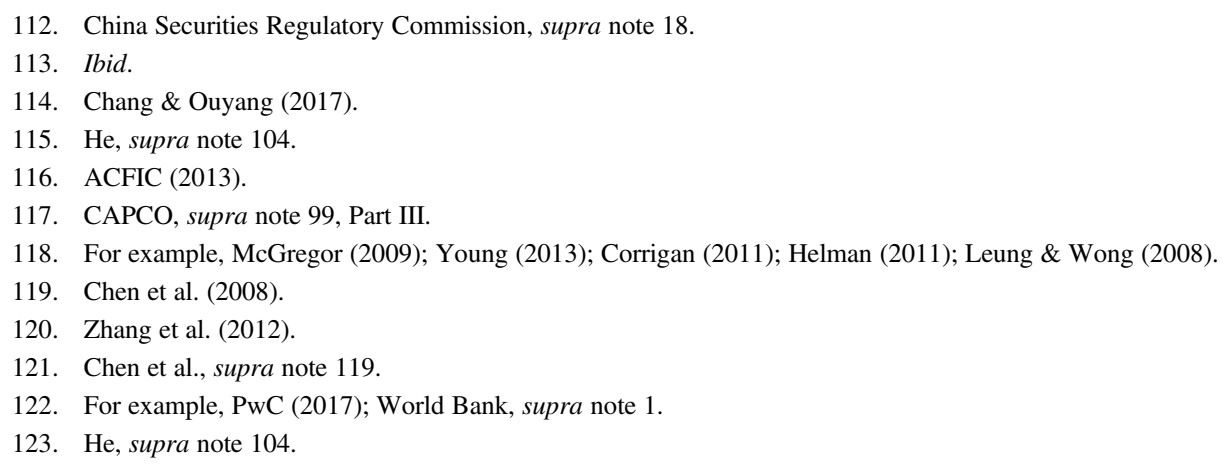


It can be seen that SOEs' dominance over the stock market and the lucrative business sectors leads to low profitability, which causes low market return, which in turn explains why the growth potential of China's stock market was limited. Apparently, there is an urgent need to profoundly reform the listed SOEs, to allow more private firms to enter the market and to break down barriers that deny private firms entry into those lucrative sectors. But China's state-sector reform has long been stuck. Even worse, some previous reform measures aiming for depoliticization and professional management have been reversed during the leadership of Xi Jinping. ${ }^{124}$ Why has there been no breakthrough in SOE reform? An answer can be found by taking a closer look at the Constitutions of both the country and the CPC, which clearly state that "public economy" is the foundation of socialist China and "state-owned economy" should be the "dominant force." Why should it be the case? Because, as Xi Jinping candidly pointed out, SOEs are the economic foundation for the CPC's rule. ${ }^{125}$ It is thus plain that, fundamentally, politics and leftist ideologies impede economic reform. If the political system is unchanged, the potential of the stock market will remain limited.

\subsection{Barriers for Law Improvement}

Although investor protection has improved, the improvement has not been sustained and fraud plagued the market again during the boom and bust of $2014-15 .{ }^{126}$ After the crisis, the government felt the need to punish some culprits. The CSRC launched another enforcement campaign, resulting in a twofold rise in the number of individuals and institutions penalized by the CSRC in 2015. ${ }^{127}$ Essentially, public enforcement of law in China takes the form of erratic campaigns and being selective- "killing a chicken to scare the monkeys." ${ }^{28}$ It lacks consistency, persistence, and real credibility. On the other hand, private enforcement by way of lawsuits brought by investors is negligible. The introduction of the shareholder derivative action into China in 2005 turns out to be "much ado about nothing" and basically no such action has ever been taken against malfeasant managers or controlling shareholders of listed companies. ${ }^{129}$ The deterrence effect of private securities litigation against misrepresentation, market manipulation, and insider trading is minimal, because the Supreme People's Court imposed various restrictions on such lawsuits and the class action was prohibited. ${ }^{130}$ Finally, the media are now muzzled and play no role in combating fraud, as do private institutions, such as Muddy Waters Research, that profits from investigating and exposing fraud. ${ }^{131}$

Why is public enforcement erratic and selective? In China, whether a law is enforced or not depends greatly on whether the top leaders are serious about it. Instead of following the law and enforcing it consistently and persistently, enforcement agencies heed the attention and direction from above. This is because, in China, top leaders, but not law, have the supreme authority and power, and enforcement agencies are not independent. The fundamental reason for the ineffectiveness of public enforcement is political. For the private

\footnotetext{
124. Hornby (2016).

125. Xinhua (2016).

126. Howie (2015); Cai (2017b).

127. China Securities Regulatory Commission, supra note 62.

128. Chen et al. (2011); Hong \& Gu (2015).

129. Zhang (2011).

130. Hutchens (2003); Huang (2013); Sheng (2014).

131. Wall Street Journal (2011).
} 
enforcement of law, first, the ultimate reason why the shareholder derivative action is useless is because the judiciary is not highly respected and trusted by the public. ${ }^{132}$ The judiciary is controlled by the CPC and the government, meaning that judges are not neutral and inferior in political and social status, which erodes public faith in their impartiality and authority. Second, the securities litigation against misrepresentation, market manipulation, and insider trading is ineffective because, in addition to the lack of authority and public faith in the judiciary, the American-styled opt-out class action is unavailable and even the opt-in group litigation permitted by the Civil Procedure Law is restricted by courts, which is in turn because of the CPC's strong suspicion of any organized activity not firmly under its control. ${ }^{133}$ The class action is not introduced and the group litigation is restricted, because grieved investors might otherwise organize themselves, posing threats to the CPC's control. The government is just not serious in empowering investors to call corporate managers to account by way of litigation, for fear of losing control. Last, the media have not played an important role in combating fraud, because the press in China is not free. Moreover, in a country where governments and business are closely connected and the police are a government department, investigative journalists have reasons to fear for their personal safety. Instead of being protected by the police from violent thugs hired by unscrupulous businesses, they may be arrested. For the same reasons as well as the fact that the CSRC stringently restricts short selling, the business model of profiting from fraud investigation and exposure is infeasible and private institutions such as Muddy Waters Research would not emerge in China. All in all, politics explains fundamentally why the improvement of investor protection has not been sustained.

\section{CONCLUSION}

China has built from scratch a complex legal and regulatory system governing the stock market, which actually played a critical role in supporting the growth of the market. It not only provided rules for the operation of the market and played other non-protective roles, but also offered investors protection. Although laws for investors protection were absent or unenforced before the early 2000s while the market grew steadily, the market fell into an existential crisis from mid-2001 and widespread fraud caused by weak law was an explanation. The market revived in 2006 after the investor protection had greatly improved and fraud was curbed. The experience of the stock market during these periods thus demonstrates that law is necessary and did play a role in sustaining market growth. However, it is crystal clear that the trajectory of development is growth first followed by law, and the strengthening of law was driven by market growth, which was in turn ultimately caused by ideological and political liberalization. On the other hand, the market did not grow to its full potential and the government has not been successful in developing the stock market to support the economy as it wishes. Currently, the market faces serious challenges to fulfil the tasks that are expected of it. The fundamental reason is political and ideological constraints. Such constraints not only restrict market growth in the first place, but also limit the improvement of law for investor protection that is necessary to sustain market growth.

132. Zhang, supra note 129.

133. Clarke (2003). 
The experience of the stock market indicates that law would be necessary to sustain China's economic growth. First, though the economy has grown rapidly so far and law might not have played a critical role in the growth, growth may not sustain if law remains weak, just as what has happened in the stock market. The stock market could be a window of the whole economy. Second, if China wishes to reach a high level of prosperity, the whole economy has to transfer to an advanced stage where economic transactions become highly impersonal just like investment in the stock market, during which law must play a more critical role. Third, the stock market is crucial to the economic growth and law is essential to the further growth of the market. Hence, law is important to the continuing growth of the whole economy. Nevertheless, the experience of the stock market also suggests that politics and ideologies are fundamental, which makes sense with regard to the whole economy. Currently, the economy is inhibited by various restrictions. To allow the economy to continue to grow, China urgently needs to push forward economic reform and liberalize the economy. However, as the stock market demonstrates, all these depend on further political and ideological relaxation. That is why many economists and policy advisers voice their opinions that China has come to a point where economic reform would not go much further without political and ideological changes. Moreover, like law for investor protection in the stock market, China's whole legal system remains substandard and inadequate. To sustain China's economic growth, the legal system has to be overhauled and law greatly strengthened. Nevertheless, without political and ideological changes, there is considerable doubt as to how far law can further strengthen in China, despite the CPC's heightened efforts to build "a socialist legal system with Chinese characteristics."

\section{REFERENCES}

21 Shiji Jingji Baodao (21 $1^{\text {st }}$ Century Business Herald) (2003) "Zhengquan Fanzui Zhenchaju Chengli, Gonganbu Quanguo Bukong Zhengquan Fanzui [Securities Crime Investigation Bureau Established and the Ministry of Public Security Targeting Securities Crimes across the Country]," 24 December.

ACFIC (All-China Federation of Industry and Commerce) (2013) "2012 Niandu Zhonghua Gongshang Shangshi Gongsi Caiwu Zhibiao Zhishu [2012 ACFIC Index of Financial Indicators of Listed Companies]," http://www.acfic.org.cn/Web/c_000000010003000100050005/d_12217.htm (accessed 21 May 2018).

Allen, Franklin, Jun Qian, \& Meijun Qian (2005) "Law, Finance, and Economic Growth in China." 77 Journal of Financial Economics 57-116.

Allen, Franklin, Jun Qian, Susan Chenyu Shan, \& Lei Zhu (2017) "Dissecting the Long-Term Performance of the Chinese Stock Market," Working Paper, https://ssrn.com/abstract=2880021 (accessed 21 May 2018).

Armour, John, Simon Deakin, Prabirjit Sarkar, Mathias Siems, \& Ajit Singh (2009) "Shareholder Protection and Stock Market Development: An Empirical Test of the Legal Origins Hypothesis." 6 Journal of Empirical Legal Studies 343-80.

BBC (2016) "China Suspends Circuit Breaker," http://www.bbc.co.uk/news/business-35253188 (accessed 21 May 2018).

Bloomberg (2017) “China's \$8.5 Trillion Shadow Bank Industry Is Back in Full Swing,” https://www. bloomberg.com/news/articles/2017-04-18/china-s-8-5-trillion-shadow-bank-industry-is-back-infull-swing (accessed 21 May 2018).

Cai, Jane (2017a) "Boom or Bust? The Big Debate Raging over China's Economic Future," South China Morning Post, 24 September. 
Cai, Jane (2017b) "Can the Head of China's Stock Market Watchdog Hunt Down Crocodiles?," South China Morning Post, 2 March.

CAPCO (China Association for Public Companies) (2012) "Zhongguo Shangshi Gongsi Fazhan Chengguo [The Achievements of China's Listed Companies]," http://www.capco.org.cn/zhuanti/ cjz/xi_znyq.html (accessed 21 May 2018).

Chang, Jie, \& Hui Ouyang (2017) "Cong 2016 Nianbao Guancha Zhongguo A Gu [An Observation of China's A Shares Based on 2016 Annual Reports]", http://opinion.caixin.com/2017-05-24/101094126.html (accessed 21 May 2018).

Chen, Bing, Jian She, Xiaojin Wang, \& Jianqing Lai (2008) "Woguo Minying Shangshi Gongsi Fazhan Shizheng Yanjiu [An Empirical Study of the Development of China's Private Listed Companies]," Research Report No. 0160, SZSE Research Institute, 14 January, http://www.szse.cn/main/files/ 2008/02/25/091811911155.pdf (accessed 21 May 2018).

Chen, Donghua, Dequan Jiang, Shangkun Liang, \& Fangping Wang (2011) "Selective Enforcement of Regulation." 4 China Journal of Accounting Research 9-27.

China Daily (1998) "China's Securities Legislation Pressing Ahead," 21 April.

China Securities Regulatory Commission (1993) "Gongkai Faxing Gupiao Gongsi Xinxi Pilu Shishi Xize (Shixing) [Detailed Implementing Rules on Information Disclosure by Publicly Issuing Companies (Trail Implementation)]," promulgated on 12 June.

China Securities Regulatory Commission (2001) "Guanyu zai Shangshi Gongsi Jianli Duli Dongshi de Zhidao Yijian [Guiding Opinion on Establishing an Independent Director System in Listed Companies]," issued on 16 August.

China Securities Regulatory Commission (2002) "Shangshi Gongsi Zhili Zhunze [Principles of Corporate Governance of Listed Companies]," issued on 7 January.

China Securities Regulatory Commission (2004) "Guanyu Jiaqiang Shehui Gongzhong Gudong Quanyi Baohu de Ruogan Guiding [Several Provisions Regarding Strengthening Protection for the Rights and Interests of Public Shareholders]," promulgated on 7 December.

China Securities Regulatory Commission (2008) "China Capital Market Development Report," http:// www.csrc.gov.cn/pub/csrc_en/Informations/publication/200911/P020091103520222505841.pdf (accessed 21 May 2018).

China Securities Regulatory Commission (2013) China Securities and Futures Statistical Yearbook, Beijing: China Statistics Press.

China Securities Regulatory Commission (2015a) "Securities Market Monthly Data (June 2015)," http://www.csrc.gov.cn/pub/csrc_en/marketdata/security/monthly/201507/t20150723_281359.html (accessed 21 May 2018).

China Securities Regulatory Commission (2015b) "Shouci Gongkai Faxing Gupiao bing Shangshi Guanli Bafa (2015 Xiuzheng) [Measures for the Administration of Initial Public Offering and Listing of Stocks, (2015 Amendment)]," issued on 30 December.

China Securities Regulatory Commission (2016) "2015 Niandu Zhongguo Zhengjianhui Jicha Zhifa Qingkuang Tongbao [Circular on the Situation of 2015 CSRC Inspection and Law Enforcement]," 15 January, http://www.csrc.gov.cn/pub/newsite/jcj/gzdt/201601/t20160122_290097.htm (accessed 21 May 2018).

Clarke, Donald C. (2003) "Corporate Governance in China: An Overview." 14 China Economic Review 371-514.

Clarke, Donald C. (2010) "Law without Order in Chinese Corporate Governance Institutions." 30 Northwestern Journal of International Law \& Business 131-99.

Clarke, Donald C., Peter Murrell, \& Susan Whiting (2008) "The Role of Law in China's Economic Development," in L. Brandt \& T. G. Rawski, eds., China's Great Economic Transformation, New York: Cambridge University Press, 375-428.

Communist Party of China (1999) "Decision of the Central Committee on Certain Important Questions Regarding SOE Reform and Development," http://cpc.people.com.cn/GB/64162/71380/71382/71386/ 4837883.html (accessed 21 May 2018).

Corrigan, Joanna (2011) "Chinese State Factory Decked Out to Look Like the Palace of Versailles," Daily Mail, 8 September. 
CPC \& State Council (1997) "Guanyu Shenhua Jinrong Gaige, Zhengdun Jinrong Zhixu, Fangfan he Huajie Jinrong Fengxian de Tongzhi [Notice on Deepening Financial Reform, Rectifying Financial Order, Preventing and Defusing Financial Risk]," http://cpc.people.com.cn/GB/64184/64186/ 66688/4494459.html (accessed 21 May 2018).

Dam, Kenneth (2006) The Law-Growth Nexus: The Rule of Law and Economic Development, Washington: The Brookings Institution.

Davis, Kevin E., \& Michael J. Trebilcock (2008) "The Relationship Between Law and Development: Optimists versus Skeptics." 56 American Journal of Comparative Law 895-946.

Er-Rafia, F-Zohra (2016) "Evaluating China's Economy," The Diplomat, 18 November.

Funk, David A. (1972) "Major Functions of Law in Modern Society." 23 Case Western Reserve Law Review 257-306.

Green, Stephen (2003) China's Stock Market: A Guide to Its Progress, Players and Prospects, London: Wiley.

Gu, Minkang, \& Robert C. Art (1996) "Securitization of State Ownership: Chinese Securities Law." 18 Michigan Journal of International Law 115-39.

Guilford, Gwynn (2015) "Behind the Chinese Government's Brazen Bid to Pump up Its Stock Market," https://qz.com/399664/behind-the-chinese-governments-brazen-bid-to-pump-up-its-stock-market/ (accessed 21 May 2018).

He, Jibao (2012) "Jingneiwai Shangshi Gongsi Fenhong de Chayi ji Yuanyin Shizheng Yanjiu [An Empirical Study of the Differences and Their Causes in Paying Dividends by Chinese and Overseas Listed Companies]," Research Report No. 0187, SZSE Research Institute, http://www.szse.cn/ main/files/2012/04/17/429275172577.pdf (accessed 21 May 2018).

Helman, Christopher (2011) "China's Sinopec Axes Exec After \$230k Booze Binge," Forbes, 26 April.

Hong, Shen, \& Wei Gu (2015) “In China's Widening Stock Crackdown, It's 'Kill the Chicken to Scare the Monkey'," Wall Street Journal, 12 November.

Hornby, Lucy (2016) "China Rows Back on State-Sector Reforms," Financial Times, 14 June.

Howie, Fraser (2015) "Fixing China's Stock Market," Wall Street Journal, 17 December.

Howson, Nicholas C. (1997) "China's Company Law: One Step Forward, Two Steps Back-A Modest Complaint." 11 Columbia Journal of Asian Law 127-73.

Hu, Ruyin (2003) Zhongguo Shangshi Gongsi Chengbai Shizheng Yanjiu [An Empirical Study of the Success and Failure of Chinese Listed Companies], Shanghai: Fudan University Press.

Huang, Robin Hui (2013) "Private Enforcement of Securities Law in China: A Ten-Year Retrospective and Empirical Assessment." 61 American Journal of Comparative Law 757-98.

Hung, Mingyi, T. J. Wong, \& Fang Zhang (2011) "The Value of Relationship-Based and Market-Based Contracting: Evidence from Corporate Scandals in China" Presented at the Inaugural Conference on China Institutions, Governance and Accounting, The Chinese University of Hong Kong, 13-14 July 2012, https://server1.tepper.cmu.edu/Seminars/docs/HWZ\%20May\%202011\%20v6_clean.pdf (accessed 21 May 2018).

Hutchens, Walter (2003) "Private Securities Litigation in China: Material Disclosure about China's Legal System.” 24 University of Pennsylvania Journal of International Law 599-689.

Ji, Weidong (2017) "Fazhi Shi Xiandai Shichang Jingji de Jichu-Wu Jinglian 'Zhongguo Gaige Sanbuqu' Duhougan [The Rule of Law is the Foundation for a Modern Market Economy-Reading Reflection on Wu Jinglian's 'A Trilogy on China's Reform'],” Caixin, 26 June, http://m.opinion. caixin.com/m/2017-06-26/101105526.html (accessed 21 May 2018).

Jiang, Zemin (1997) "Report to the 15th Congress of CPC," 12 September, http://cpc.people.com.cn/ GB/64162/64168/64568/65445/4526285.html (accessed 21 May 2018).

Kan, Zhidong (2010) Rongru Ershi Nian: Wo de Gushi Rensheng [Ups and Down: The Kan Zhidong Story], Beijing: CITIC Publishing Group.

KPMG (2017) "Mainland China and Hong Kong 2017 Review: IPOs and Other Market Trends," https://assets.kpmg.com/content/dam/kpmg/cn/pdf/en/2017/12/china-hk-ipo-2017-review.pdf (accessed 21 May 2018).

Kuhn, Anthony (2001) “Chinese Markets 'Worse than a Casino'," Los Angeles Times, 29 March. 
Leung, Alison, \& Ruth Wong (2008) "CITIC Pacific Warns Potential \$2 Billion Forex Losses," Reuters, 20 October.

Li, Jing (2001) "Shuizai Caocong Yi' an Keji? [Who is Manipulating Yi'an Keji?]," Caijing, 5 June.

Li, Zhangzhe (2011) Zhongguo Gushi Fengyun Dangan [Archives of the tumultuous History of China's Stock Market], Beijing: Zhongguo Jingji Chubanshe.

Ling, Huawei, \& Shuo Wang (2001) "Yinguanxia Xianjing [The Trap of Yinguanxia]," Caijing, 5 August.

Ling, Huawei, Haili Cao, \& Fan Zhou (2006) "Xiaoxiong Tang Wanxin [Tang Wanxin: The Villian]," Caijing, 9 January.

Liu, Guy S., \& Pei Sun (2005) "The Class of Shareholding and Its Impacts on Corporate Performance: A Case of State Shareholding Composition in Chinese Public Companies." 13 Corporate Governance: An International Review 46-59.

Liu, Hongru (2008) Tupo-Zhongguo Ziben Shichang Fazhan zhi Lu [Breaking Through-The Road of China's Capital Market Development], Beijing: Zhongguo Jinrong Chubanshe.

Lu, Yi (2008) Xianbuzhu de Shou-Zhongguo Gushi Tizi Jiyin Yanhuashi [Restless Hands-The Gene Evolution of China's Stock Market System], Beijing: CITIC Publishing Group.

Luo, Peixing (2005) "Zhengquan Weifa Weigui Chengjie Shixiao he Zhidu Chengben Yanjiu [Research on the Effectiveness and Institutional Cost of Sanctions against Violation of Securities Laws and Regulations]," Project Report No. 15 SSE Joint Research Program, https://biz.sse.com.cn/ cs/zhs/xxfw/jysjs/sseResearch/2005lawsnrules/2005lawsnrules_c.pdf (accessed 21 May 2018).

McGregor, Richard (2001) "Crackdown on Corruption Splits Beijing," Financial Times, 13 February.

McGregor, Richard (2009) "Sinopec's Corrupt Ex-Chief Gets Death Sentence," Financial Times, 16 July.

Milhaupt, Curtis J., \& Katharina Pistor (2008) Law and Capitalism: What Corporate Crises Reveal about Legal Systems and Economic Development around the World, Chicago: University of Chicago Press.

National Bureau of Statistics of China (1994) "Statistical Communiqué of PRC," http://data.stats.gov. $\mathrm{cn} /$ publish/index $? \mathrm{~m}=$ (accessed 21 May 2018).

NBSC (1980) "Statistical Communiqué of PRC," http://data.stats.gov.cn/publish/index?m (accessed 21 May 2018).

NBSC (1988) "Statistical Communiqué of PRC," http://data.stats.gov.cn/publish/index?m= (accessed 21 May 2018).

New York Times (2009) "Interviews with Wu Jinglian, Shelley Wu and Wu's Biographer," http:// www.nytimes.com/2009/09/27/business/global/27spy-text.html (accessed 21 May 2018).

North, Douglass (1990) Institutions, Institutional Change, and Economic Performance, Cambridge: Cambridge University Press.

NPC (1997) "Zhonghua Renmin Gongheguo Xingfa [Criminal Law of PRC]," adopted on 14 March.

NPCSC (1995) "Guanyu Chengzhi Weifan Gongsifa de Fanzui de Jueding [Decision Regarding the Punishment of Crimes in Violation of the Company Law]," adopted on 28 February.

NPCSC (2005) "Zhonghua Renmin Gongheguo Zhengquan Fa [Securities Law of PRC]," adopted on 27 October.

NPCSC (2006) "Zhonghua Renmin Gongheguo Xingfa Xiuzhengan (Liu) [Amendments 6 to the Criminal Law of PRC]," adopted on 29 June.

Pan, Yuan (2001) "Da Bianlun: Gushi Shifou Yao Tuidao Chonglai, Nao Chang Geming Fengbao? [Great Debate: Should the Stock Market Be Revolutionized by Closing It Down and Start All Again?]," Zhongguo Qingnian Bao (China Youth Daily), 26 November.

People's Bank of China (1990) "Zhengquan Gongsi Guanli Zanxing Banfa [Interim Measures on the Administration of Securities Companies]," promulgated on 12 October.

Pi, Haizhou (2001) “'Jiyougu': Rangwo Ruhe gan Maini? ['Blue Chip Stocks': How Dare I Buy you?]," Zhengquan Ribao (Securities Daily), 10 October.

Pistor, Katharina, \& Chenggang Xu (2005) "Governing Stock Markets in Transition Economies: Lessons from China." 7 American Review of Law and Economics 184-210. 
PwC (2017) "Paying Taxes," https://www.pwc.com/gx/en/paying-taxes/pdf/pwc-paying-taxes-2017. pdf (accessed 21 May 2018).

Rabinovitch, Simon (2013) "IPOs Set to Resume in China," Financial Times, 30 November.

Renmin, Ribao (1996) "Zhengque Renshi Dangqian Gupiao Shichang [Correctly Understanding the Current State of the Stock Market]," People's Daily, 16 December.

Rheinstein, Max (1954) Max Weber on Law in Economy and Society, Cambridge: Harvard University Press.

Shanghai Municipal Government (1984) "Guanyu Faxing Gupiao de Zanxing Guanli Banfa [Interim Measures on the Administration of Share Issuance]," promulgated on 10 August, http://www.lawlib.com/law/law_view.asp?id=46101 (accessed 21 May 2018).

Sheng, Jin (2014) "Private Securities Litigation in China: Passive People's Courts and Weak Investor Protection." 26 Bond Law Review 94-147.

Shi, Yongdong, \& Jiang Xianfeng (2005) "Zhongguo Zhengquan Shichang Weifa Weigui Xingwei de Panbie-Jiyu Neimu Jiaoyi yu Shichang Caozong de Anli Fenxi [Detection and Discrimination of Illegal Activities in Chinese Security Market-Case Studies of Insider Trading and Market Manipulation]." 24 Yuce (Forecasting) 77-81.

Shleifer, Andrei, Simeon Djankov, Rafael LaPorta, \& Florencio Lopez-de-Silanes (2008) "The Law and Economics of Self-Dealing." 88 Journal of Financial Economics 430-65.

State Administration for Industry and Commerce (1985) "Gongsi Dengji Guanli Zanxing Guiding [Interim Provisions on the Administration of Company Registration]," 14 August, http://www.lawlib.com/law/law_view.asp?id=46832 (accessed 21 May 2018).

State Council (1992) "Guanyu Jinyibu Jiaqiang Zhengquan Shichang Hongguan Guanli de Tongzhi [Notice on Further Strengthening Macro Administration of Securities Markets]," promulgated on 17 December.

State Council (1993a) "Jinzhi Zhengquan Qizha Xingwei Zanxing Banfa (Interim Measures on Preventing Securities Fraud)," promulgated on 2 September.

State Council (1993b) "Zhengquan Faxing yu Jiaoyi Guanli Zanxing Tiaoli [Interim Regulations on the Administration of Share Issuance and Trading]," promulgated on 22 April.

State Council (2004) "Guanyu Tuijing Ziben Shichang Gaige Kaifang he Wending Fazhan de Ruogan Yijian [Certain Opinions on Advancing Reform, Opening-Up and Stable Development of the Capital Markets]," promulgated on 31 January.

Trebilcock, Michael, \& Jing Leng (2006) "The Role of Formal Contract Law and Enforcement in Economic Development." 92 Virginia Law Review 1517-80.

Upham, Frank (2013) "What Are Property Rights Good for? Insights from the Chinese Experience," in G. Yu, ed., Rethinking Law and Development: The Chinese Experience, Oxford: Routledge, 82-104.

Wall Street Journal (2011) "Sino-Forest Plunges After Negative Research Report,” Wall Street Journal, 3 June.

Wall Street Journal (2012a) "Lardy vs. Pettis: Debating China's Economic Future," http://blogs.wsj. com/chinarealtime/2012/11/02/lardy-vs-pettis-debating-chinas-economic-future/ (accessed 21 May 2018).

Wall Street Journal (2012b) "Lardy vs. Pettis: Debating China's Economic Future, Round 2," http:// blogs.wsj.com/chinarealtime/2012/11/07/lardy-vs-pettis-debating-chinas-economic-future-round-2/ (accessed 21 May 2018).

Walter, Carl E., \& Fraser J. T. Howie (2006) Privatizing China: Inside China's Stock Markets, Singapore: John Wiley \& Sons (Asia) Pte. Ltd.

Wang, Hui (2005) "Dagudong Guanlian Zhankuan Falu Duice Yanjiu [Research on Legal Countermeasures to Misappropriation by Related Parties of Large Shareholders]." Gongsi Falu Pinglun (Company Law Review) 88-99.

Wang, Ting (2009) "Zhongguo Zhengquan Jicha Zhifa Zhidu Bianqian yu Shizheng Yanjiu [The Evolution of the Inspection and Enforcement Institution in China's Securities Market: An Empirical Study]," PhD diss., Wuhan University.

Wang, Xiaolu (2012) “Zhengjian xin Qiju [CSRC's New Chess Game],” Caijing, 16 July. 
Williamson, Oliver (1985) The Economic Institutions of Capitalism, New York: The Free Press.

Williamson, Oliver (1996) The Mechanisms of Governance, New York: Oxford University Press.

World Bank (2017) "World Bank National Account Data_GDP Growth," https://data.worldbank.org/ indicator/NY.GDP.MKTP.KD.ZG?locations $=\mathrm{CN}$ (accessed 21 May 2018).

Wu, Jinglian, Junkuo Zhang, Wei Lv, Guoqiang Long, \& Chunlin Zhang (1997) "Shixian Guoyou Jingji de Zhanluexing Gaizu-Guoyou Qiye Gaige de Yizhong Silu [Realizing Strategic Restructuring of State-Owned Economy_One Way of Thinking about SOE Reform]." 13 Gaige (Reform) $12-22$.

Xiao, Gang (2013) "Jianguan Zhifa: Ziben Shichang Jiankang Fazhan de Jishi [Supervision and Enforcement: The Bedrock for a Healthy Capital Market]." 15 Qiushi (Seek Truth) 29-31.

Xie, Andy (2014) "Only the Rule of Law Can Ensure Sustained Prosperity in China," South China Morning Post, 29 May.

Xin Jing Bao (Beijing News) (2008) "Jiemi Zhongguo Gushi Shouzhi Jicha Zongdui [Demystifying China's First Securities Enforcement Contingent]," 30 January.

Xinhua (2008) "China's 4 Trillion Yuan Stimulus to Boost Economy, Domestic Demand," http://news. xinhuanet.com/english/2008-11/09/content_10331324.htm (accessed 21 May 2018).

Xinhua (2010) "China Reports Record 9.59 Trillion Yuan in Loans in 2009," http://news.xinhuanet. com/english/2010-01/15/content_12816059.htm (accessed 21 May 2018).

Xinhua (2014) "Guanyu 'Zhonggong Zhongyang Guanyu Quanmian Tuijin Yifa Zhiguo Ruogan Zhongda Wenti de Jueding' de Shuoming [Explanatory Notes on the 'CPC Central Committee Decision concerning Several Major Issues in Comprehensively Advancing Governance According to Law']," http://news.xinhuanet.com/politics/2014-10/28/c_1113015372.htm (accessed 21 May 2018).

Xinhua (2016) "Xi Jinping zai Quanguo Guoyou Qiye Dangjian Gongzuo Huiyishang Qiangdiao: Jianchi Dang dui Guoqi de Lingdao bu Dongyao [Xi Jinping Emphasizes at the National SOE Party Construction Meeting: To Uphold Party's Leadership over SOEs Unfaltering]," 11 October.

Xu, Xiaonian (2001) "Gushi Tiaozheng Lakai Xumu [The Prelude to a Stock Market Adjustment Has Started]," Caijing, 5 October.

Xu, Zhifeng (2012) "Gushi Xiadie Cunzai Konghuangxing Yinsu [Panic Selling Causing the Stock Market Slump]," Renmin Ribao, 1 August.

Young, Doug (2013) "Corporate Crackdown Nets Chalco, China Mobile Execs," South China Morning Post, 21 November.

Yu, Jeanny (2017) "In China's Strange Bull Market, Most Stocks Are Retreating," Bloomberg, 7 December.

Zhang, Ed, \& Huang Ying (2012) "Stimulus 2.0' Aims to Reboot Growth," China Daily, 1 June.

Zhang, Hua, Xiaohua Li, \& Weijiong Zhang (2012) "Gao Ying Shou, Di Ying Li-2012 Minying Shangshi Qiye Jixiao Baogao [High Incomes, Low Profits-Report on the Financial Performance of Listed Private Companies in 2012]," Zhong Ou Shangye Pinglun (CEIBS Business Review), Issue 55, http://www.ceibsreview.com/show/index/calssid/2/id/2109 (accessed 21 May 2018).

Zhang, Joe (2013) Inside China's Shadow Banking: The Next Subprime Crisis?, Honolulu: Enrich Professional Publishing.

Zhang, Shidong (2017) "CSRC Says State Meddling Stabilises China Stock Market," South China Morning Post, 16 August.

Zhang, Xian Chu (1999) "The Old Problem, the New Law, and the Developing Market: A Preliminary Examination of the First Securities Law of the People's Republic of China." 33 The International Lawyer 983-1014.

Zhang, Zhong (2011) "The Shareholder Derivative Action and Good Corporate Governance in China: Why the Excitement Is Actually for Nothing." 28 Pacific Basin Law Journal 174-209.

Zhao, Ziyang (1987) "Yanzhe you Zhongguo Tese de Shehuizhuyi Daolu Qianjin: Zai Zhongguo Gongchandwang di Shisanci Quanguo Daibiao Dahui Shang de Baogao [March along the Road to Socialism with Chinese Characters: Report to the $13^{\text {th }}$ Congress of CPC]," http://cpc.people.com.cn/ GB/64162/64168/64566/65447/4526369.html (accessed 21 May 2018). 